\title{
Author Index to Volume $12-1985$
}

Anderson, B.A.: 129 (May) Applegarth, D.A.: 274 (Aug)

Bailey, P.: 278 ( Aug) Berger, L.: 255 (Aug)

Bernstein, M.: 366 (Nov supplement)

Bilbao, J.M.: 321 (Nov)

Biovin, D.: 106 (Mijy)

Blume, W.T.: 317 (Nov)

Bolton, C.F.: 303 (Nov)

Bourque, C.N.: 129 (May)

Boyd, M.C.: 31. 35 (Feb)

Calne, D.B.: 314 (Nov)

Camfield, P.R.: 48 (Feb)

Carroll, D.J.: 39 (Feb)

Carruthers, J.: 314 (Nov)

Chan-Lui, W.Y.: 100 (May)

Chiu. M.C.: 341 (Nov supplement)

Chu, J.Y.: 69 (Fcb)

Cochrane, D.D.: 51 (Feb)

Cohen, H.C.M.: 12I (May)

Colapinto, E.V.: 321 (Nov)

Cooper, P.W.: 65 (Feb)

Cooperberg, P.L.: 31 (Feb)

Corenblum, B.: 243 (Aug)

Corrado, C.: 336 (Nov supplement)

Cosgrove. J.B.R.: 106 (May)

Couch, R.: 48 (Feb)

Cowan, D.H.: 69 (Feb)

Crapper Mcl_achlan, D.T.: 1 (Fcb)

Darwish, H.Z.: 95 (May)

Decary, F.: 106 (May)

del Campo, C.M.: 129 (May)

Derome, P.J.: 345 (Nov supplement)

Dixon, A.A.: 267 (Aug)

Dolan, E.J.: 65 (Feb)

Dooley, J.M.: 73 (Fcb)
Dua, A.K.: 60 (Feb)

Duquette, P.: 106 (May)

Ebers, G.C.: 236 (Aug)

Eder, S.: 317 (Nov)

Eisen, A.: 314 (Nov)

Etches, W.S.: 39 (Feb)

Earin-Waters, C.: 272 (Aug)

Farrell, K.: 274 (Aug)

Freigang, $B .: 45$ (Feb)

Garner, J.B.: 267 (Aug)

Gauthier, S.: 255 (Aug)

Gentili, F.: 336 (Nov supplement)

Ghanem, Q.: 136 (May)

Gilbert, J.: 149 (May)

Gilbert, J.J.: 303 (Nov)

Gordon. P.A.: 39 (Feb)

Griebel, R.: 259 (Aug)

Gutin, P.H.: 366 (Nov supplement)

Hansebout, R.R.: 83 (May)

Haslam, R.H.A.: 45 (Feb)

Hoffman, H.J.: 348 (Nov supplement)

Hogenhuis, L.A.H.: 308 (Nov)

Holness, R.O.: 267 (Aug)

Howes, W.J.: 267 (Aug)

Huang, K.: 88 (May)

Hudson, A.R.: 32I (Nov)

Jackson, A.1.: 303 (Nov)

Jasper, H.H.: 221 (Aug)

Jeffrey, V.: 39 (Feb)

Kamath, M.V.: 83 (May)

Kassel, E.E.: 65 (Feb)

Khan, M.: 259 (Aug)

Kwan, H.C.: 11. 24 (Feb)

Lamont, R.N.: 83 (May)

Lamoureux, G.: 106 (May)
Lang, A.E.: 125 (May). 272 (Aug)

Lapierre, Y.: I06 (May)

Lasjaunias, P.: 341 (Nov supplement)

Leblanc, R.: 255 (Aug)

Lewis, A.J.: 65.69 (Feb)

Lewis, P.N.: 1 (Feb)

Logan, W.J.: 100 (May)

Lougheed, W.M.: 336 (Nov supplement)

Luo, Y.: 88 (May)

Mak, E.: 314 (Nov)

Marsh, L.: 39 (Feb)

Martin, W.R.W.: 6 (Feb)

Mertens, W.C.: 317 (Nov)

McLeod, P.M.: 274 (Aug)

Morley, T.P.: 230 (Aug)

Morrice, B.L.: 39 (Feb)

Muller, P.: 371 (Nov supplement)

Murphy, J.T.: 11, 24 (Feb)

Murray, T.J.: 251 (Aug)

Myles, S.T.: 51 (Feb)

Nimrod, C.: 51 (Feb)

Noseworthy, J.: 149 (May)

Olmstead, D.: 39 (Feb)

Pascual-Castroviejo, I.: 139 (May)

Payne, D.G.: 363 (Nov supplement)

Pinsky, C.: 60 (Feb)

Pleines, J.: 106 (May)

Politis, M.: 259 (Aug)

Potts, D.G.: 327 (Nov supplement)

Resch, L.: 272 (Aug)

Reulen, J.P.H.: 308 (Nov)

Robitaille, Y.: 278 (Aug)

Ross, R.T.: 289 (Nov)

Rozdilsky, B.: 259 (Aug)
Sanders, E.A.C.M.: 308 (Nov)

Sarnat. H.B.: 111 (May). 296 (Nov)

Savage, A.V.: 274 (Aug)

Saunders, F.W.: 263 (Aug)

Schwartz, M.L.: 65 (Feb)

Scott, A.: 314 (Nov)

Sharpe, J.A.: 332 (Nov supplement)

Shedden, P.: 263 (Aug)

Sima, A.A.F.: 129 (May')

Smyth, H.: 358 (Nov supplement)

Steinbok. P.: 31. 35 (Feb)

Still, D.K.: 51 (Feb)

Sugarman, R.G.: 51 (Feb)

Sundaram, M.B.M.: 134 (May)

Tator, C.H.: 353 (Nov supplement)

Taylor, M.J.: 100 (May)

Ter Brugge, K.G.: 341 (Nov supplement)

Tibbles, J.A.R.: 48 (Feb)

Toone, V.R.: 274 (Aug)

Tsui. J.K.: 314 (Nov)

Tucker, W.S.: 121 (May)

Tyndel. F.: 321 (Nov)

Van der Velde, E.A.: 308 (Nov)

Van Orman, C.B.: 95 (May)

Warren, K.G.: 39 (Feb)

Wells, G.A.: 317 (Nov)

Wilson, B.C.: 371 (Nov supplement)

Wittman, B.K.: 51 (Feb)

Wright, B.A.: 73 (Feb)

Wong, Y.C.: 11, 24 (Feb)

Wu, L.: 88 (May)

Yamashiro, K.: 336 (Nov supplement) Young, G.B.: 303,317 (Nov)

Zimmerman, R.D.: 327 (Nov supplement)

\section{Subject Index to Volume $12-1985$}

Adrenoleukodystrophy

Adrenoleukodystrophy Mimicking Multiple Scle. rosis 73 (Feb)

Akinetic Mutism

Akinetic Mutism and Parkinsonism Associated with Obstructive Hydrocephalus 255 (Aug)

Alzheimer's Disease

Alzheimer's Discase: Errors in Gene Expression I (Feb)

Amantadine

Amantadine Therapy for Fatigue in Multiple Sclerosis 251 (Aug)

Angiography, super-selective

Super-selective Angiography and Embolization of Skull Base Tumours 341 (Nov supplement)

Asthma

Cough Syncope Mimicking Epilepsy in Asthmatic Children 45 ( Feb)

Ataxia Telangectasia

Longitudinal Evoked Potential Studies in Heredi-

tary Ataxias 100 (May)

Autoimmune Disease

Sensorimotor Perineuritis - An Autoimmune Diseasc"? 129 (May)

Basal Skull

Super-selective Angiography and Embolization of Skull Base Tumours 341 (Nov supplement)
Binswanger's Disease

Binswanger`s Disease: Progressive Subcortical Encephalopathy or Multi-Infarct Dementia? 88 (May)

Botulinum Toxin

A Pilot Study on the Use of Botulinum Toxin in Spasmodic Torticollis 314 (Nov)

Brain

Le Cerveau Influence-t-il le Développement Musculaire du Foetus Humain? 11 ( May)

Carotid Artery

The Carotid Siphon: A Scanning Electron Microscope Assessment of it 's Embolic Potential 263 (Aug)

Cerebral Infarcts

Binswanger`s Disease: Progressive Subcortical Encephalopathy or Multi-Infarct Dementia? 88 (May)

Chemotherapy

Complications of Chemotherapy 149 (May)

Chorea

Recurrent Chorea Gravidarum in Four Pregnancies 136 (May)

Complications

Complications of Chemotherapy 149 (May)

Cortex, Motor

Cross Correlation Studies in Primate Motor Cortex:
Event Related Correlation 24 (Feb)

Cross Correlation Studies in Primate Motor Cortex:

Synaptic Interaction and Shared Input II (Feb)

Cough Syncope

Cough Syncope Mimicking Epilepsy in Asthmatic Children 45 (Feb)

Craniopharyngioma

Craniopharyngiomas 348 (Nov supplement)

Creutzfeldt-Jakob Disease

Cocxistence of Idiopathic Parkinson's Disease and Creutzfeldt-Jakob Disease 272 (Aug)

Dementia

Binswanger's Disease: Progressive Subcortical Encephalopathy or Multi-Infarct Dementia? 88 (May)

Dopamine

delta-Opioid Modulation of Striatal Dopaminergic Activity in Mice 60 (Feb)

Embolization, Angiographic

Super-selective Angiography and Embolization of Skull Base Tumours 341 (Nov supplement)

Encephalopathy

The Encephalopathy of Sepsis 303 (Nov)

Epilepsy

Cough Syncope Mimicking Epilepsy in Asthmatic

Children 45 (Feb)

Differential Aspects of Sleep Epilepsy 317 (Nov) 
Evoked Potentials

Cross Correlation Studies in Primate Motor Cortex:

Event Related Correlation 24 (Feb)

Electrophysiological Disorders in Multiple Sclerosis and Optic Neuritis 308 (Nov)

Longitudinal Evoked Potential Studies in Hereditary Ataxias 100 (May)

Monitoring of Sensory Evoked Potentials during Surgery of Skull Base Tumours 336 (Noy supplement)

Evolution

The Brain of the Planarian as the Ancestor of the Human Brain 296 (Nov)

Fatigue

Amantadine Therapy for Fatigue in Multiple Sclerosis 251 (Aug)

Fetus

Intrauterine Hydrocephalus and Ventriculomegaly

Associated Abnomalies and Fetal Outcome 51

(Feb)

Le Cerveau Influence-t-il le Développement Musculaire du Foetus Humain? 111 (May)

Friedreich's Ataxia

Longitudinal Evoked Potential Studies in Hereditary Ataxias 100 (May)

Gliomatosis, Leptomeningea

Primary Diffuse LeptomeningealGliomatosis 278 (Aug)

Haemorrhage, Intracerebral

Spontaneous Intracerebral Haemorrhage: An Analysis of Factors Affecting Prognosis 267 (Aug)

Hemangioma Calcificans

Hemangioma Calcificans of the Spinal Cord 321 (Nov)

Hematomyelin

Hemangioma Calcificans of the Spinal Cord 321 (Nov)

Hemiballismus

Persistent Hemiballismus with Lesions Outside the Subthalamic Nucleus 125 (May)

History

Osler and Neurology 236 (Aug)

Some Professional and Political Events in Canadian Neurosurgery 230 (Aug)

The Early Development of Neuroscience in Canada 221 (Aug)

Hydrocephalus

Akinetic Mutism and Parkinsonism Associated with Obstructive Hydrocephalus 255 (Aug)

Hydrocephalus, Intrauterine

Intrauterine Hydrocephalus and Ventriculomegaly Associated Abnomalies and Fetal Outcome 5 (Feb)

Immunological Disease

IgDK Multiple Myeloma Presenting as Unilateral Proptosis 69 (Feb)

Invertebrate Brain

The Brain of the Planarian as the Ancestor of the Human Brain 296 (Nov)

Magnetic Resonance Imaging

Nuclear Magnetic Resonance Imaging of Skul Base Lesions 327 (Nov supplement)

Medical Treatment

The Medical Treatment of the Hypersecreting Pituitary Gland 243 (Aug)

Meninges

Primary Diffuse LeptomeningealGliomatosis 278 (Aug)

Movement Disorders

Positron Emission Tomography in Movement Disorders 6 (Feb)

Multiple Myelom

IgDK Multiple Myeloma Presenting as Unilateral Proptosis 69 (Feb)
Multiple Sclerosis

A Double-blind Controlled Pilot Study of Plasma Exchange Versus Sham Apheresis in Chronic Progressive Multiple Sclerosis 39 (Feb)

Amantadine Therapy for Fatigue in Multiple Sclerosis 251 (Aug)

Clinical Sub-groups of Multiple Sclerosis in Relation to HLA: DR Alleles as Possible Markers of Disease Progression 106 (May)

Electrophysiological Disorders in Multiple Sclerosis and Optic Neuritis 308 (Nov)

Muscle Development

Le Cerveau Influence-t-il le Développement Musculaire du Foetus Humain? III (May)

Myelography

Pitfalls of Incomplete Myelography with Thoracic Spinal Lesions 121 (May)

Neonate

Efficacy of Phenobarbital in Neonatal Seizures 95 (May)

Neuroma, Acoustic

Acoustic Neuromas: Management of 204 cases 353 (Nov supplement)

Neuropathy

Sensorimotor Perineuritis - An Autoimmune Disease? 129 (May)

Neuroscience

The Early Development of Neuroscience in Canada 221 (Aug)

Neurosurgery

Some Professional and Political Events in Canadian Neurosurgery 230 (Aug)

Neurosyphilis

Pupillary Abnormalities in Congenital Neurosyphilis 134 (May)

Optic Neuritis

Electrophysiological Disorders in Multiple Sclerosis and Optic Neuritis 308 (Nov)

Osler, Sir William

Oster and Neurology 236 (Aug)

Parkinsonism

Akinetic Mutism and Parkinsonism Associated with Obstructive Hydrocephalus 255 (Aug) delta-Opioid Modulation of Striatal Dopaminergic Activity in Mice 60 (Feb)

\section{Parkinson's Disease}

Coexistence of Idiopathic Parkinson's Disease and Creutzfeldt-Jakob Disease 272 (Aug)

Perineuritis

Sensorimotor Perineuritis - An Autoimmune Disease? 129 (May)

Phenobarbital

Efficacy of Phenobarbital in Neonatal Seizures 95 (May)

\section{Photodynamic Therapy}

Photodynamic Therapy (PDT): Cavitary Photoillumination of Malignant Cerebral Tumours using a Laser Coupled Inflatable Balloon - A Preliminary Report 371 (Nov supplement)

Pineal Tumour

Pineal Region Tumors 35 (Feb)

Pituitary Tumours

The Medical Treatment of the Hypersecreting Pituitary Gland 243 (Aug)

Planarian

The Brain of the Planarian as the Ancestor of the Human Brain $2 \%$ (Nov)

\section{Plasmapheresis}

A Double-blind Controlled Pilot Study of Plasma Exchange versus Sham Apheresis in Chronic Progressive Multiple Sclerosis 39 (Feb)

Positron Emission Tomography

Positron Emission Tomography in Movement Disorders 6 (Feb)
Pregnancy

Recurrent Chorea Gravidarum in Four Pregnancies 136 (May)

Proptosis

IgDK Multiple Myeloma Presenting as Unilateral Proptosis 69 (Feb)

Pseudoarylsulfatase-A Deficiency

Pseudoarylsulfatase-A Deficiency in the Neurologically Impaired Patient 274 (Aug)

Pseudotumor Cerebri

The Changing Picture of Pseudotumor Cerebri in Children 48 (Feb)

Radiation Therapy

Interstitial Irradiation of Skull Base Tumours 366 (Nov supplement)

Radiation Therapy of Tumours involving the Skull Base 363 (Nov supplement)

Seizures

Efficacy of Phenobarbital in Neonatal Seizures 95 (May)

Sepsis

The Encephalopathy of Sepsis 303 (Nov)

Shunt Ventricular

Intrauterine Hydrocephalus and Ventriculomegaly: Associated Abnomalies and Fetal Outcome 51 (Feb)

Spinal cord

Hemangioma Calcificans of the Spinal Cord 321 (Nov)

Pitfalls of Incomplete Myelography with Thoracic Spinal Lesions 121 (May)

Spinal Cord Infarction in Disease and Surgery of the Aorta 289 (Nov)

The Effects of Local Cooling on Canine Spinal Cord Blood Flow 83 (May)

Spinal Cord Injury

Hemorrhagic Changes in Experimental Spinal Cord Injury Models 259 (Aug)

Synaptic Interaction

Cross Correlation Studies in Primate Motor Cortex: Synaptic Interaction and Shared Input 1$\}$ (Feb)

Torticollis, Spasmodic

A Pilot Study on the Use of Botulinum Toxin in Spasmodic Torticollis 314 (Nov)

Trigeminal Nerve

Adenoid Cystic Carcinoma: An Unusual Neurosurgical Entity 65 (Feb)

Tumour

Adenoid Cystic Carcinoma: An Unusual Neurosurgical Entity 65 (Feb)

Tumour, Brain

Intraoperative Localization of Intracranial Lesions with Real Time UItrasound 31 (Feb)

Pineal Region Tumors 35 (Feb)

Tamour, Pituitary

Pathological Diversity in Clinical Syndromes of Pituitary Hypersecretion: Its significance in evaluating their surgical treatment 358 (Nov supplement

Tumour, Skull Base

325-373 (Nov supplement)

Ultrasound

Intraoperative Localization of Intracranial Lesions with Real Time Ultrasound 31 (Feb)

Vascular Malformations

The Association of Extracranial and Intracranial Vascular Malformations in Chiłdren 139 (May)

Ventriculomegaly

Intrauterine Hydrocephalus and Ventriculomegaly: Associated Abnomalies and Fetal Outcome 51 (Feb)

Visual Dysfunction

Visual Dysfunction with Basal Skull Tumours 332 (Nov supplement) 
THE CANADIAN JOURNAL OF NEUROLOGICAL SCIENCES

SPECIAL FEATURES

Message from the Editor

Alzheimer's Disease: Errors in Cene Expression ................. D.T. Crapper MClachlan and P.N. Lewis

Positron Emission Tomography in Movement Disorders ............ W.R. Wayne Martin ORIGINAL ARTICLES

Cross Correlation Studies in Primate Motor Cortex: Synaptic Interaction and Shared Input ........................................... /ohn T. Murphy, Hon. C. Kwan and Yiu C. Wong Cross Correlation Studies in Primate Molor Cortex: Event Related Correlation john T. Murphy, Hon. C. Kwan and Yiu C. Wong Intraoperative Localization of Intracranial Lesions with Real Time Ultrasound ........... Michacl C. Boyd, Paul Steinbok and Peter L. Cooperberg Pineal Region Tumors ................................. Michael C. Boyd and Paul Steinbok Pineal Region Tumors .................................. Michael C. Boyd and Paul Steinbok
A Double-blind Controlled Pilot Study of Plasma Exchange versus Sham Apheresis in Chronic Progressive Multiple Sclerosis .......... P.A. Cordon, D.I. Carroll, W.S. Etches, V. Jefirey, L. Marsh, B.L. Morrice, D. Olmstead and K.G. Warren Cough Syncope Mimicking Epilepsy in Asthmatic Children ........ Robert H. A. Haslam and Bruno Freigang

1
6

11

24

31

35

39

45

\section{THE CANADIAN JOURNAL OF NEUROLOGICAL SCIENCES}

ORIGINAL ARTICLES

The Effects of Local Cooling on Canine Spinal Cord Blood Flow Roberl $R$. Hansebout, $R$ Neil Lamont and $M$ Venkatraya Kamath Roberl R. Hansebout, R. Nell Lamont and M. Venkatraya Kamath Binswanger's Disease: Progressive Subcortical Encephalopathy or Multi-Infarct
Dementia? ........................................................ Kewei Huang, Lijuan Wu and Yi Luo Eementia? ........................................... Kewei Huang, Lijuan WU and Yi Luo Longitudinal Evoked Potential Studies in Hereditary Ataxias ....................... Taylor, W.Y. Chan-Lui and W.J. Logan 100

Clinical Sub-Groups of Multiple Sclerosis in Relation to HLA:

Dr. Alleles as Possible Markers of Disease Progression .................. Pierre Duquette. Francine Decary, Juliana Pleines, Denise Biovin. Cilles Lamoureux, lames B.R. Cosgrove and Yves Lapierre 106 Le Cerveau Influence-t-il le Developpement Musculaire du Foetus Humain? pitfalls or incomplete Myelography with Thoracic Spinal Lesions Harvey B. Sarnat Hart CM Cohen and William S. Tucker Persistent Hemiballismus with Lesions Outside the Subthalamic Nucleus

\section{THE CANADIAN JOURNAL OF NEUROLOGICAL SCIENCES}

\section{SPECIAL FEATURES}

The Early Development of Neuroscience in Canada ...................... Herbert $\mathrm{H}$. lasper 221 Some Professional and Political Events in Canadian Neurosurgery

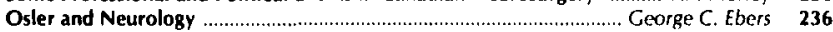
ORIGINAL ARTICLES

The Medical Treatment of the Hypersecreting Pituitary Gland .... Bernard Corenblum 243 Amantadine Therapy for fatigue in Multiple Sclerosis ............................. T.J. Murray 251 Akinetic Mutism and Parkinsonism Associated with Obstructive Hydrocephalus L. Berger, S. Gauthier and R. Leblanc 255 Hemorrhagic Changes in Experimental Spinal Cord Injury Models .......... Moe Khan, Robert Criebel. Bodan Rozdilsky and Michael Politis 259 The Carotid Siphon: A Scanning Electron Microscope Assessment of its Embolic F.W Saunders and $P$ Shedden

\section{THE CANADIAN IOURNAL OF NEUROLOGICAL SCIENCES}

\section{SPECIAL FEATURES}

Spinal Cord Infarction in Disease and Surgery of the Aorta

The Brain of the Planarian as the Ancestor of the Human Brain

ORIGINAL ARTICLES

The Encephalopathy of Sepsis

Alan C. Jackson, Joseph I. Gilbert C. Bryan Young and Charles F. Bolton Electrophysiological Oisorders in Multiple Sclerosis and Optic Neuritis ....................... E.A.C.M. Sanders, I.P.H. Reulen, L.A.H. Hogenjuis and E.A. van der Velde A Pilot Study on the Use of Botulinum Toxin in Spasmodic Torticollis ......... I.K. Tsui, A. Eisen, E. Mak. I. Carruthers, A. Scott and D.B. Calne Differential Aspects of Sleep Epilepsy ................. G. Bryan Young, Warren T. Blume, George A. Wells, Wilson C. Mertens and Suzanne Eder 317

VOL. 12, NO. 1 FEB. 1985

The Changing Piclure of Pseudotumor Cerebri in Children ...................... R. Couch, P.R. Camfield and I.A.R. Tibbles Intrauterine Hydrocephalus and Ventriculomegaly: Associated Abnomalies and Felal Outcome ............... D.D. Cochrane, S.T. Myles, C. Nimrod, D.K. Still, R.C. Sugarman Telta-Opiod Modulation of Striatal Dopaminergic Activity in Mice and B.K. Wittman and Carl Pinsky Adenoid Cystic Carcinoma: An Unusual Neurosurgical Entity ........... Eugen I. Dolan Michael L. Schwartz, Anthony I. Lewis, Edward E. Kassel and Perry W. Cooper IgDK Multiple Myeloma Presenting as Unilateral Proptosis ................. Joseph Y. Chu. Anthony I. Lewis and Donald H. Cowan Adrenoleukodystrophy Mimicking Multiple Sclerosis .... I.M. Dooley and B.A. Wright CORRESPONDENCE

IN MEMORIAM: Kenneth Edwin Livingston M.D., D.A.B.N., F.A.C.S., F.R.C.S. (C) ... BOOK REVIEWS

CALENDAR OF EVENTS Sensorimotor Perineuritis _ An Autoimmune Diseasel ..... Christopher N. Bourque. Pupillary Abnormalities in Congenital Neurosyphilis Recurrent Chorea Gravidarum in Four Pregnancies .............................. Quais Chanem 136 REVIEW ARTICLE

The Association of Extracranial and Intracranial Vascular Malformations in Children

CLINICOPATHOLOGICAL CONFERENCE: -

Complications of Chemotherapy .................................... /. Cilberl and/. Noseworthy 149

IN MEMORIAM - Norman Geschwind (1926-1984) tenacio Pascual-Castrovicio 139

BOOK REVIEWS ....

NOTES AND ANNOUNCEMENTS

CALENDAR OF EVENTS

XX CANADIAN CONGRESS OF NEUROLOGICAL SCIENCES -

Program and Abstracts

VOL. 12, NO. 3 AUG. 1985

Spontaneous Intracerebral Haemorrhage: An Analysis of Factors Affecting Prognosis A A Dixon RO Holness, W H. Howes and $1 B$. Carner Coexistence of Idiopathic Parkinson's Disease and Creutzfeldt-Jakob Disease ...........
C. Ezrin-Waters, L. Resch and A.E. Lang Pseudoarylsulfatase - A Deficiency in the Neurologically Impaired Patient Kevin Farrell, D.A. Applegarth. I.R. Toone. P.M. McLeod and A.V. Savage Primary Diffuse Leptomeningeal Gliomatosis ........... Peter Bailey and Yves Robitaille CORRESPONDENCE

BOOK REVIEWS

NOTES AND ANNOUNCEMENTS

CALENDAR OF EVENTS

Hemangioma Calcificans of the Spinal Cord ............... Felix 1. Tyndel, Juan M. Bilbao, Alan R. Hudson and Edward V Colapinto 321

SPECIAL SUPPLEMENT

Symposium on Skull Base Tumours (see detailed Table of Contents) BOOK REVIEWS

NOTES AND ANNOUNCEMENTS

CALENDAR OF EVENTS

CANADIAN CONGRESS OF NEUROLOGICAL SCIENCES -

INDEX TO VOLUME 12 